\title{
Remediation of Polar Ecosystems Polluted by Gas Condensate and Oil Hydrocarbons by Biological Preparations
}

\author{
Rauf V. Galiulin* and Rosa A. Galiulina
}

Institute of Basic Biological Problems of Russian Academy of Sciences, Pushchino, Moscow Region, 142290, Russian Federation

\begin{abstract}
Assessment of degradation of gas condensate and oil hydrocarbons in a sample of soil illuvial horizon as Polar ecosystems part and soil model for degradation under action of new biological preparations (Bioros and Piksa) in experimental conditions showed that degradation of gas condensate in soil, for example, under Bioros action was faster than degradation of oil. After application of Piksa the process of oil degradation in soil was much faster. The activity of catalase and dehydrogenase enzymes increased with enhanced quantity of biological preparations used for oil contaminated soil remediation.
\end{abstract}

Keywords: Polar ecosystems, soil model for degradation, gas condensate, oil, biological preparations, degradation, enzymatic activity.

\section{INTRODUCTION}

Gas condensate and oil, i.e. mixtures of liquid hydrocarbons of various classes (paraffines, naphthenes, arenes), are significant environment contaminants in gas and oil industry. It is known that gas condensate drops out from gas solution under pressure reduction (gas recovery from stratum), has lower density $\left(0.7-0.8 \mathrm{~g} / \mathrm{cm}^{3}\right)$ compared to oil $(0.8-1.1$ $\mathrm{g} / \mathrm{cm}^{3}$ ) and contains fewer heteroatomic compounds (resins and asphaltenes, including apart from carbon and hydrogen atoms sulfur, nitrogen and oxygen atoms). Production and transmission of gas condensate and oil lead to their spills caused by accidents under various circumstances. For example, in 2005 the unauthorized (criminal) condensate pipeline insert in the Orenburg region resulted in the release of $145 \mathrm{~m}^{3}$ of gas condensate, which caused contamination of 4.5 ha of soil and 0.7 ha of water (Gendel et al. 2006). In 2008, the depressurization of a condensate pipeline at a gas processing plant in the Republic of Komi resulted in the spill of about $25 \mathrm{~m}^{3}$ of condensate, part of which run to water streams (Ovanesyants et al. 2008). In June 2006, the unauthorized oil pipeline insert in the Samara region resulted in the spill of about $500 \mathrm{~m}^{3}$ of oil, which caused contamination of $\sim 1.2$ ha of agricultural lands; in October in the same region $\sim 6$ ha of plough lands were similarly contaminated (Ovanesyants et al. 2006; 2007). In the Chelyabinsk region the accident at the trunk oil pipeline caused the spill of approximately $400 \mathrm{~m}^{3}$ of oil, part of which run to water streams; the contaminated area amounted to $\sim 1000 \mathrm{~m}^{2}$. In 2007 , the hydraulic hammer in the Saratov region caused the rupture of the pipe buried at $1.2 \mathrm{~m}$ depth along the weld seam, which resulted in the spill

*Address correspondence to this author at the Institute of Basic Biological Problems of Russian Academy of Sciences, Pushchino, Moscow Region, 142290, Russian Federation; E-mail: rauf-galiulin@ rambler.ru of $300 \mathrm{~m}^{3}$ of oil (Ovanesyants et al. 2007a). The total contaminated area, including agricultural lands and water body, amounted to $\sim 25$ ha. In 2008 the corrosion of an oil pipeline in the Samara region caused the leak of water-oil emulsion, which resulted in contamination of $2200 \mathrm{~m}^{2}$ of soil (Ovanesyants et al. 2009).

The contamination by liquid hydrocarbons reduces the quality and efficiency of soils, lands are taken out from the agricultural fund. For example, the site on the territory of a booster compressor station (the Stavropol territory) had no vegetation and "oil" layer in the soil profile due to longlasting penetration of gas condensate from a vent stack (Bukhgalter et al. 2008). According to (Koronelly 1996), the level of soil contamination by hydrocarbons of $5 \%$ from the soil mass $(50 \mathrm{~g} / \mathrm{kg})$ does not allow to use it for agricultural purposes, therefore, this issue should be addressed using scientific methods. There are examples of biochemical monitoring of oil-contaminated soils carried out during 3-10 years, which shows that natural remediation is a long process (Kireeva et al. 2002). Thus, the search for and testing of efficient remediation methods for oil- and gas condensatecontaminated soils based on the destructive capacity of hydrocarbon-oxidizing microorganisms - bacteria, yeasts or filamentous fungi - used in the form of biological preparations is very important. The former is lyophilically dried (under low temperature and in vacuum) microorganism biomass, the latter is compositions made by accelerated fermentation of turf-excrement or turf-manure and other mixtures and enriched by hydrocarbon-oxidizing microflora and nutrient substances. Testing of biological preparations as remediation means is reasonable to carry out in the laboratory, where the impact of different factors on gas condensate and oil hydrocarbons degradation can be simulated (quantity, temperature, etc.) and the required information for further field studies can be quickly obtained. 
The work is aimed at investigation of gas condensate and oil hydrocarbons degradation under simulated conditions in a sample of soil illuvial horizon as Polar ecosystems part and soil model for degradation under action of two new biological preparations - Bioros and Piksa.

\section{MATERIALS AND METHODS}

Bioros is based on two physiological groups of microorganisms - Rhodococcus sp. bacteria and Candida sp. yeast, total quantity $10^{10}$ cell/g (Akopova 2008, Listov et al. 2008). Used Piksa (Premium) is made by accelerated fermentation of turf-manure mixture and enriched by hydrocarbonoxidizing microorganisms in the quantity of $10^{6}$ cells/g and nutrient substances (Sementsov 2006). The stated quantity of these microorganisms in the Piksa is considered sufficient for self-reproduction and impact on neighboring populations (Koronelly 1996).

The investigation of gas condensate and oil hydrocarbons degradation was carried out on an averaged sample of soil illuvial horizon $\left(50-90 \mathrm{~cm}\right.$ layer, heavy clay loam, $\mathrm{pH}_{\mathrm{H} 2 \mathrm{O}}$ 6.2) as soil model for degradation. The soil sample was treated with gas condensate and oil in the amount of $50 \mathrm{~g} / \mathrm{kg}$, and after that Bioros was introduced (0.1 and $0.5 \mathrm{~g} / \mathrm{kg}$ ). During the other test Piksa was introduced $(50$ and $100 \mathrm{~g} / \mathrm{kg}$ ) to the soil treated with oil (50 and $100 \mathrm{~g} / \mathrm{kg}$ ). The Bioros was introduced to the soil in the form of suspension made by solution homogenization of ammophoska (6 g/l) performed by air barbotage for 3 hours. Soil samples treated with gas condensate, oil and biological preparations incubated in plastic reservoirs (250 ml volume) under constant humidity $70 \%$ from maximum water holding capacity: first 20 days under temperature $+8^{\circ} \mathrm{C}$ and other 20 days - under $+18^{\circ} \mathrm{C}$. The latter was connected with simulation of perennial temperature changes in the studied soil layer in May-July.

On the $10^{\text {th }}$ and $40^{\text {th }}$ day, the content of gas condensate and oil hydrocarbons was analyzed by infrared spectrometry using IKN-025 concentration meter. For this purpose $50 \mathrm{ml}$ of carbon tetrachloride $(5 \mathrm{~min})$ were used for extraction $1 \mathrm{~g}$ of soil sample lot by Ekros-8000 extractor. After settlement (10 min) the extract was fed to the chromatographic column with $\mathrm{Al}_{2} \mathrm{O}_{3}$ and the content of gas condensate and oil hydrocarbons was analyzed using the concentration meter. To confirm the microbiological nature of degradation, in particular of oil hydrocarbons, on the $40^{\text {th }}$ day the activity of catalase $\left(\mathrm{ml} \mathrm{O}_{2} /(\mathrm{min} \cdot \mathrm{g})\right.$ ) and dehydrogenase ( $\mathrm{mg} \mathrm{2,3,5-triphenyl-}$ formazan/(g.day)) enzymes was measured by patented gas metric and colorimetric methods respectively (Bashkin et al. 2010; 2010a).

The statistic processing of results was performed at confidence interval adopted for ecotoxicological studies for an average value of different variants calculated at the significance level $P_{1}=0.05$. The results of the analysis of the content of gas condensate and oil hydrocarbons were used to calculate the time of their practically full degradation, i.e. by $99 \%\left(T_{99}\right)$ under the exponential relation: $y=e^{-k t}$, where $y-$ residual hydrocarbons content at time $t$, related to the initial; $e$ - base of the natural logarithm; $k$ - hydrocarbon degradation velocity constant. The corresponding formula for calculation is as follows: $T_{99}=\ln 100 / \mathrm{k}$.

\section{CONCEPTUAL BASIS OF HYDROCARBON DEG- RADATION IN SOIL UNDER BIOLOGICAL PREPA- RATIONS ACTION}

The use of the sample of underlying soil layers, i.e. its illuvial horizon as Polar ecosystems part, for investigation of gas condensate and oil hydrocarbons was not accidental. The studies (Kalachnikova et al. 1985) carried out on podzolic illuvial-humus soil (the Middle Obya) showed that for a year after treatment oil penetrated to the depth of $50 \mathrm{~cm}$, passed illuvial horizons and reached the groundwater table. Observations (Pikovskii et al. 1985) revealed that in the earth storage designed for spilled oil sequestration a powerful intersoil flow of hydrocarbons moving to the place of ground waters off-loading was identified in silty-gley soil profile (humid subtropic zone). The upper boundary of the flow was identified at 50-60 cm depth and the lower boundary linked with the groundwater table. Thus, studies of underlying soil layers are of certain scientific interest, since, on the one hand, they allow to estimate gas condensate and oil hydrocarbons degradation under conditions of 1-2 orders smaller quantity of microorganisms of various physiological groups compared to upper soil layers. On the other hand, it allows the researcher to identify better the remediation capacity of tested biological preparations. As for hydrocarbons microbiological degradation, this process performed by, in particular, Rhodococcus bacteria included into Bioros involves absorption of substances by hydrophobization of the cell wall implemented through biosynthesis of specific compounds lipophil glycol-, peptide- and peptideglycollipids (Koronelly 1996). In case of a direct contact of bacteria with a hydrocarbon film the latter penetrate into the cell by passive diffusion - gradual penetration into the cell wall - and reach enzymes on membranes. Along with molecular-diffuse penetration of hydrocarbons through the surface of the cell wall, they can penetrate through special ultra-microscopic pores as well. Such channels filled with electron-dense (granular) substance were first found in yeasts, one strain of this physiological group of microorganisms is included into Bioros as a second active component.

The analysis of catalase and dehydrogenase activity carried out during the investigation was caused by their direct participation in hydrocarbons degradation. Catalase accelerates hydrocarbons oxidation by hydrogen peroxide, destroying last to oxygen necessary for this reaction, and dehydrogenase catalyzes hydrogen abstraction from hydrocarbon oxidation products molecules (dehydration reaction). The involvement of hydrogen peroxide in this biochemical reaction is caused by its generation in the process of microorganisms breathing and hydrocarbon oxidation.

The use of exponential relation for calculation of the time of practically full hydrocarbon degradation $\left(T_{99}\right)$ under action of biological preparations was also logical. It was observed (Vodopyanov et al. 2004) that the oil-contaminated soil experienced the exponential reduction of phytotoxicity level, 
Table 1. Time of practically full degradation $\left(T_{9 g}\right)$ of gas condensate and oil hydrocarbons in a sample of soil illuvial horizon (50-90 cm layer) under Bioros biological preparation action.

\begin{tabular}{|c|c|}
\hline Variant & $\boldsymbol{T}_{99}$ \\
\hline \hline Gas condensate, $50 \mathrm{~g} / \mathrm{kg}+$ Bioros, $0.1 \mathrm{~g} / \mathrm{kg}$ & 125 \\
\hline Gas condensate, $50 \mathrm{~g} / \mathrm{kg}+$ Bioros, $0.5 \mathrm{~g} / \mathrm{kg}$ & 56 \\
\hline Oil, $50 \mathrm{~g} / \mathrm{kg}+$ Bioros, $0.1 \mathrm{~g} / \mathrm{kg}$ & 171 \\
\hline Oil, $50 \mathrm{~g} / \mathrm{kg}+$ Bioros, $0.5 \mathrm{~g} / \mathrm{kg}$ & 61 \\
\hline
\end{tabular}

Table 2. Time of practically full degradation $\left(T_{99}\right)$ of oil hydrocarbons in a sample of soil illuvial horizon $(50-90 \mathrm{~cm}$ layer) under Piksa biological preparation action.

\begin{tabular}{|c|c|}
\hline Variant & $\boldsymbol{T}_{99}$ \\
\hline \hline Oil, $50 \mathrm{~g} / \mathrm{kg}$ & 329 \\
\hline Oil, $50 \mathrm{~g} / \mathrm{kg}+$ Piksa, $50 \mathrm{~g} / \mathrm{kg}$ & 184 \\
\hline Oil, $50 \mathrm{~g} / \mathrm{kg}+$ Piksa, $100 \mathrm{~g} / \mathrm{kg}$ & 69 \\
\hline Oil, $100 \mathrm{~g} / \mathrm{kg}$ & 1150 \\
\hline Oil, $100 \mathrm{~g} / \mathrm{kg}+$ Piksa, $50 \mathrm{~g} / \mathrm{kg}$ & 658 \\
\hline Oil, $100 \mathrm{~g} / \mathrm{kg}+$ Piksa, $100 \mathrm{~g} / \mathrm{kg}$ & 288 \\
\hline
\end{tabular}

which usually coincides with the decrease of hydrocarbons due to their microbiological degradation.

\section{RESULTS AND DISCUSSION}

The time of practically full hydrocarbon degradation of gas condensate hydrocarbons reduced by 46 and 5 days respectively compared to oil hydrocarbons at treatment of a soil sample by different quantities of Bioros (0.1 and 0.5 $\mathrm{g} / \mathrm{kg}$ ) which is caused by lower content of arenes, resins and asphaltenes that are less accessible for microorganisms than paraffins and naphthenes in the former (Table 1). Soil treatment by Piksa (50 and $100 \mathrm{~g} / \mathrm{kg}$ ) reduced the time of oil hydrocarbons degradation process in case of oil concentration $50 \mathrm{~g} / \mathrm{kg}$ by 1.8 and 4.8 times, $100 \mathrm{~g} / \mathrm{kg}$ - by 1.7 and 4.0 times (Table 2).

The activity of catalase and dehydrogenase increased with the growing quantity of used biological preparations at different levels of soil contamination with oil (50 and 100 $\mathrm{g} / \mathrm{kg}$ ), in case of Piksa by 9-27 and 4.7-15.6 times, Bioros by 7-31 and 3.7-18.8 times respectively (Table 3 ).

Enzymatic diagnostics of gas condensate hydrocarbons degradation process performed earlier in field conditions showed that under action of different quantities of Piksa (4$16 \mathrm{~kg} / \mathrm{m}^{2}$ ) the activity of catalase and dehydrogenase of heavy clay loam chernozem soil increased in average by 1.92.8 and 5.7-8.9 times (Bukhgalter et al. 2008) respectively.

The increased enzymatic activity at application of biological preparations confirms the microbiological nature of gas condensate and oil hydrocarbons degradation. Studies (Teranishi et al. 1974) have shown that yeasts that grew on hydrocarbons have a direct connection between the increased quantity of peroxisomes (organelles in cell cytoplasm) and increased activity of catalase with this enzyme. However the observed reduced enzymatic activity at increased soil contamination level in several cases has different reasons,

Table 3. Catalase and dehydrogenase activity of soil illuvial horizon $(50-90 \mathrm{~cm}$ layer) contaminated oil sample under introduction of Piksa and Bioros biological preparations.

\begin{tabular}{|c|c|c|}
\hline Variant & \multicolumn{2}{|r|}{ Activity of } \\
\hline Oil, $50 \mathrm{~g} / \mathrm{kg}$ & 0.1 & 0.13 \\
\hline Oil, 50 g/kg + Piksa, 50 g/kg & 1.5 & 0.74 \\
\hline Oil, $50 \mathrm{~g} / \mathrm{kg}+$ Bioros, $0.1 \mathrm{~g} / \mathrm{kg}$ & 3.1 & 2.18 \\
\hline Oil, $50 \mathrm{~g} / \mathrm{kg}+$ Bioros, $0.5 \mathrm{~g} / \mathrm{kg}$ & 2.9 & 2.45 \\
\hline Oil, $100 \mathrm{~g} / \mathrm{kg}$ & 0.1 & 0.15 \\
\hline Oil, $100 \mathrm{~g} / \mathrm{kg}+$ Bioros, $0.1 \mathrm{~g} / \mathrm{kg}$ & 0.7 & 0.55 \\
\hline Oil, $100 \mathrm{~g} / \mathrm{kg}+$ Bioros, $0.5 \mathrm{~g} / \mathrm{kg}$ & 1.1 & 1.43 \\
\hline
\end{tabular}


including development of anaerobic conditions, direct inhibition of catalytic activity of enzymes or delay of their synthesis by microorganisms at suppression of the latter growth under the impact of oxidized hydrocarbon products, such as hexadecyl spirit, palmic, benzoic, salycilic acids, etc. (Kolesnikov et al. 2006).

\section{CONCLUSION}

Thus, the studies revealed the evident advantage of such laboratory tests that allow to quickly, for a relatively short time period, get required information compared to more long-lasting field tests. The tests identified the possibility of efficient use of tested biological preparations for remediation of gas condensate- and oil- contaminated soils. The next stage of studies comprises targeted field tests at territories with the major risk of soil contamination in case of accidental gas condensate and oil spills. They will finally determine the preferable application of Bioros or Piksa biological preparations on the basis of "price-environmental efficiency" correlation.

\section{CONFLICT OF INTEREST}

The authors confirm that this article content has no conflict of interest.

\section{ACKNOWLEDGEMENTS}

We thank Prof., Dr (Biol.) Vladimir N. Bashkin, principal researcher, Gazprom VNIIGAZ LLC \& Institute of Physicochemical and Biological problems RAS, for constructive comments.

\section{REFERENCES}

Akopova, GS (2008) Biopreparation cleaning of technogenic environments contaminated by hydrocarbons. Gas Industry, 6, 69-71.

Bashkin, VN, Bukhgalter, EB, Galiulin, RV, Konyaev, SV, Kalinina, IE, \& Galiulina, RA (2010) Control Method for Cleaning of Soils Contaminated by Hydrocarbons and Neutralization of Hydrocarbons Sludge by Catalase Activity Analysis, RU Patent 2387995.

Bashkin, VN, Bukhgalter, EB, Galiulin, RV, Konyaev, SV, Kalinina, IE, \& Galiulina, RA (2010a) Control Method for Cleaning of Soils Contaminated by Hydrocarbons and Neutralization of Hydrocarbons Sludge by Dehydrogenase Activity analysis, RU Patent 2387996.
Bukhgalter, EB, Galiulin, RV, Bashkin, VN, Sidorova, IE, Grunvald, AV, Sementsov AYU, \& Galiulina, RA (2008) Remediation of soil contaminated by gas condensate. Protection of the Environment in Oilgas Complex, 2, 6-18.

Gendel, GL, Kleimenova, IE, Donetskova, AA, Belikova, NG, \& Ivanovskaya, IB (2006) Peculiarities of works realization on land cleaning disturbed and contaminated by break-down of condensate pipeline. Protection of the Environment in Oilgas Complex, 6, 669.

Kalachnikova, IG, Maslivets, TA, Oborin, AA, Ogloblina, AI \& Pikovskii, YuI (1985) Transformation of oil in podzolic soils of Middle Priobya. Migration of Contaminating Substances in Soils and Adjoining Environments. Leningrad: Gidrometeoizdat Publishing House, 7480 .

Kireeva, NA, Novoselova, EI, \& Onegova, TS (2002) Catalase and dehydrogenase activity in soils contaminated by oil and oil products. Agrochemistry, 8, 64-72.

Kolesnikov, SI, Kazeev, KSh, Tatosyan, ML, \& Valkov, VF (2006) Influence of contamination by oil and oil products on biological state of ordinary chernozem. Soil Science, 5, 616-20.

Koronelly, TV (1996) Principles and intensification methods of biological degradation of hydrocarbons in the environment (review). Applied Biochemistry and Microbiology, 32, 579-85.

Listov, EL, Akopova, GS, \& Balakirev, IV (2008) Technology optimization of «Bioros» preparation production on experimental installation of VNIIgaz LLC. Protection of the Environment in Oilgas Complex, 8, 9-13.

Ovanesyants, AM, Krasilnikova, TA, \& Ivanov, AB (2007). Environmental pollution and radiation situation on the Russian Federation territory in October 2006. Meteorology and Hydrology, 1, 115-20.

Ovanesyants, AM, Krasilnikova, TA, \& Ivanov, AB (2007a) Environmental pollution and radiation situation on the Russian Federation territory in January 2007. Meteorology and Hydrology, 4, 105-09.

Ovanesyants, AM, Krasilnikova, TA, \& Ivanov, AB (2008) Environmental pollution and radiation situation on the Russian Federation territory in June 2008. Meteorology and Hydrology, 9, 102-06.

Ovanesyants, AM, Krasilnikova, TA, \& Ivanov, AB (2009) Environmental pollution and radiation situation on the Russian Federation territory in October 2008. Meteorology and Hydrology, 1, 101-08.

Ovanesyants, AM, Krasilnikova, TA, \& Segida, IN (2006) Environmental pollution and radiation situation on the Russian Federation territory in June 2006. Meteorology and Hydrology, 9, 99-105.

Pikovskii, YuI, Veselovskii, VA, Vshivtsev, VS, Ernestova, LS, \& Biya, LA (1985) Geochemical and ecological study of oil flows in moist subtropics zone. Migration of Contaminating Substances in Soils and Adjoining Environments. Gidrometeoizdat Publishing House, Leningrad, pp. 64-9.

Sementsov, AYU (2006) «Piksa»Supercompost Use for Urban Soils Reabilitation. Methods Recomendations. VNIIA Publishing House, Moscow, p. 32

Teranishi, Y, Kawamoto, S, Tanaka, A, Osumi, M, \& Fukui, S (1974) Induction of catalase activity by hydrocarbons in Candida tropicalis pK 233. Agricultural and Biological Chemistry, 38, 1221-25.

Vodopyanov, VV, Kireeva, NA, \& Tarasenko, EM (2004) Phytotoxicity of oil contaminated soils (mathematical modeling). Agrochemistry, 10, 73-7. 